\title{
Needs for In-service Professional Development of Teachers to Improve Students' Academic Performance in Sub-Saharan Africa
}

\author{
Oluwatoyin Ayodele Ajani* \\ Department of Education, Faculty of Education, University of Zululand, KwaDlangezwa, Kzn, South Africa
}

\begin{abstract}
This study examined the impacts of in-service professional development activities on the academic performance of students in Nigerian secondary schools, using secondary schools in Lagos, a state in Nigeria as a case study. The outcomes of this study revealed that relevant, very objective and well designed in-service professional development of teachers promote effective instructional tasks delivery of teachers, which lead to better academic performance in
\end{abstract} internal and external examinations.

In-service professional development is important to quality education; it equips teachers (through seminars, workshops, conferences, mentorship and other activities) with relevant, current and effective knowledge, skills, values and attitudes that promote academic excellence in teaching and learning in school system. These activities (if well designed) improved teaching skills of participating teachers and ensure better academic performance of the learners.

This paper, therefore recommends variety of well designed, purposeful, relevant, learner-centred teaching skills and regular professional development structures for all teachers to promote quality education and excellent performance in learners' academic.

A Learner-Centred In-Service Professional Development Model (LIPD) was also designed for the effective professional development of teachers in this study. A model that will make in-service professional development of teachers to be functional to teaching and learning in schools.

Keywords: In-service; Professional development; Academic performance; Quality education; Instructional tasks.

\section{Introduction}

Education is the bedrock of development. No nation can develop without sound education. Education has over the years been given much attention and priority in African countries, especially in Nigeria, the government at all levels, has discovered that the quality of education offered in Nigerian educational system determines the quality of development experienced. Education prepares the citizens for variety of functions within the economic, social, political, religious and other structures of the societies. It makes individuals responsive, responsible and acceptably fit in to the society. The needs for teachers to be regularly updated and developed continually to better their professional capabilities as regarding instructional delivery in their subject knowledge cannot be undermined.

Mkhwanazi defines teacher professional development as all changes in teaching approaches teachers can acquire towards teaching profession [1]. All in-service professional development activities, teachers can access within the teaching profession, to develop their teaching and learning tasks towards learners improved academic performance. Professional development of teachers helps them to acquire relevant and new skills, ideas, knowledge to develop teaching and learning of their subjects (Ravhuhali). Teachers cannot rely only on the entry knowledge they start the career with, they need to experience professional growth like other professions. Their efficiency is measured or determined with learners' academic performance. Teachers are to be regularly developed to teach effectively. Their efficiency shows from their learners' academic performance. In country like South Africa, mass failure of learners in subjects prompt Department of Education to call for professional development of teachers. The practices in the developed countries are different from this, teachers are programmed for different professional development activities that can improve them further or sustain the quality education they have attained.

For quality education to be achieved and sustained, teachers are to be exposed to effective professional development activities by the education leaders, scholars, service providers, policymakers and other stakeholders in Nigeria. Teachers' mastery of the subjects gets improved due to skills acquired in professional development. In the training activities, experienced facilitators are used to multi-task teachers' intelligences to problem solving skills which improve their knowledge of their subjects. Academic performance of learners must be the driving force for teachers to be regularly developed. Teachers are to be exposed to various professional activities that can boost or promote development in all ramifications; Nigeria desires to be technologically developed like other developed countries and to really sustain her "giant" of Africa title. The needs for teachers' empowerment through rigorous and well planned varieties of professional development of teachers across the profession should not be undermined. Drive for professional development of teachers in Nigerian schools will also propel other African countries to follow suit.

*Corresponding author: Oluwatoyin Ayodele Ajani, Department of Education, Faculty of Education, University of Zululand, KwaDlangezwa, Kzn, South Africa Tel +27 35902 6950; E-mail: oaajani@gmail.com

Received January 06, 2018; Accepted February 19, 2018; Published February 24, 2018

Citation: Ajani OA (2018) Needs for In-service Professional Development of Teachers to Improve Students' Academic Performance in Sub-Saharan Africa. Arts Social Sci J 9: 330. doi: 10.4172/2151-6200.1000330

Copyright: (c) 2018 Ajani OA. This is an open-access article distributed under the terms of the Creative Commons Attribution License, which permits unrestricted use, distribution, and reproduction in any medium, provided the original author and source are credited. 


\section{Theoretical Framework}

Researchers' concerns to integrate effective model for improved teaching skills necessitate this review. This paper integrates theoretical framework that elaborates the importance of professional development activities as what Nigerian teachers needed.

The effectiveness in professional development of teachers has been a driving force for professionalism of teachers across the globe Bantwini [2]. Professional development aims at bringing out best teaching practices that can promote effective learning and better academic performance. The theoretical framework deepens the needs for Nigerian teachers to access regular and befitting professional activities that will improve learners' academic performance in every subject, thereby making every learning to have whole learning experience in schools.

According to Steyn collaborations among teachers remain an effective way of promoting effective teaching as against the usual traditional belief of individual-teacher practice [3]. This promotes sharing of knowledge, ideas, skills, and values among teachers for better and improved instructional tasks delivery in various subject areas. Clustering of teachers who teach same subject, with the quest for learning that can improve their instructional task delivery in classes, become necessity for teachers. The teachers come together, rub minds and brainstorm together on various common tasks they need for teaching improvement. They agree with the facilitators who are also experienced in the subject, for proper perception of their needed aids for improvement for classroom teaching. Garet, Porter, Desimone, Birman and Yoon are of the opinion that teachers through in-service professional development learn better and faster while interacting with one another in the same teaching profession, most importantly, colleagues and senior colleagues from same specialization [4]

The Social learning theories of Wenger thus, establish the teacher professional learning perspectives which promote quality education through regular and effective participations in in-service professional programmes for the teachers. In establishing this synthesis, Nigerian teachers are units of social environment, their interactions that are planned to brainstorm or fashion better solutions to common issues in their teaching experience in classroom, can produce learning skills that can be extended to their learners in the course of teaching and learning. We submit that collaborations through various avenues of professional development for teachers result in:

- Improved teaching skills for teachers where learners are the focus: learner-centred. Involvement of teachers on regular basis for variety of professional development activities enables them to be updated and improved on modern skills of instructional task delivery.

- Knowledge is shared among the teachers to promote mastery of their subject matters. When two or more teachers converge, they pool their wealth of experience together and also benefit from older or experienced teachers from their discipline.

- It empowers teachers to avail themselves all means to make learning concrete and real: facilitation of real learning. Curiosity of teachers to deliver, to improve learners' skills

- Improved social interactions that build confidence in them.

- Develop teachers to be researchers in new ideas in their areas of specialization.

- Mentoring opportunities among the experienced and young teachers.
Andragogy theory is another theoretical framework that this study integrates to needs for professional development for teachers in Nigeria. Knowles theory of andragogy submits four indicators that anchor the nature and patterns of needs for in-service professional development activities for teachers that can promote quality of education though learning experience from professional development activities that prompt applicable learning experiences that teachers can adopt into their classroom teaching:

(a) Teachers need to know why they need to learn something; teachers would not just attend professional development that does not impact their teaching skills. They need quality professional development activities that address their challenges in teaching methods or new curriculum.

(b) Teachers need to learn experientially, learning to them is effective and much appreciated if the facilitators of such professional activities are experienced, versatile and competent teachers from their specialized subjects. These facilitators build confidence in them as they actually know their challenges and needs in the subjects.

(c) Teachers need to access learning as problem-solving. It is known fact that teachers are in need of problem solving skills in their instructional task delivery in schools. Activities that can make learners learn easily are what teachers are looking forward to in any professional development activity.

(d) Teachers learn effectively when the knowledge is of immediate benefits to them. Teachers would always be eager to attend professional development activities that can improve their teaching. They desire knowledge that can be applied to classroom situations.

\section{An overview of professional development for teachers}

Recent challenges in education system of Nigeria has identified the needs for teachers in various primary and post primary institutions in Nigerian schools to have regular access to in-service professional development activities. Present state of education clamours for effective IPD programmes can reposition the teachers for better productivity in the system. Quality and purposeful IPD that will promote teachers' knowledge and skills improve their teaching practice and improve learners' performance. Hirsh reveals three important features of an effective professional development for teachers: (a) a deep understanding of a particular subject content is the nucleus of an effective in-service professional development; (b) the perceptions and beliefs of individualteacher determine what he/she learns or accept in the trainings; and (c) a well articulated design for learning experience to be acquired and post-evaluation of professional development programmes to determine the impacts on teaching and learning [5].

Various approaches used in in-service professional development of teachers include workshops, seminars and conferences, with missions and visions to improve teachers' knowledge and skills, using facilitators who are usually from outside the school system [6]. These are not practically teachers who can use realities in classrooms to facilitate such trainings. Desimone et al suggest that professional development that could not influence teaching practices in schools should be discontinued [7].

Lee calls for in-service professional development programmes that could be longer and effective, this goes beyond few days or few weeks trainings but longer ones that would entail deep and practical learning that can really impact teachers' skills and subjects' knowledge. Inservice professional development activities can be most effective when 
they are regular, constant, relevant and can be accessed by every teacher [6]. In-service professional development of teachers can be effective if the activities are longer time framed, teachers of same subject specializations and grades are pulled together to focus on common subject contents [7]. The focus of IPD can be identified as follow:

Teachers' learning needs: Various in-service professional development programmes should be designed to meet varieties of subjects and teachers needs for different subject-contents and grades. Professional development can only become effective when teachers apply learnt knowledge from professional development programmes if they are based on their subject areas, when this occurs, it is believed that teachers are growing professionally in their career. These programmes have to be sustained and relevant to them. Teachers love to have activities that are practically inclined in professional development programmes.

Teachers' readiness to learn: Teachers will always be ready to learn in any professional development workshops or activities that can make them learn new knowledge, help them handle classroom challenges for their subjects or the programmes whose conceptions are theirs [7].

Effectiveness of school leadership: The only way to determine the effectiveness of school leadership is by the academic performance of learners, schools with effective leadership structures will always promote regular and quality in-service professional development activities for the teachers. Their commitment for quality education is manifested in their support for quality professional development programmes for the teachers [8]. The leaders also identify the needs of teachers and design or recommend appropriate trainings to improve the teachers.

The school learning environment context: Teachers 'participation and acquisition of learning experience are determined by variables in the school learning environment context that may either enhance or obstruct the professional learning of teachers [9]. Variables such as school cultural background, teacher collaboration and the school environment influence teachers' commitment to professional development and therefore also impact effectiveness of these professional development activities. Subject-cluster teachers adopt strengths and complement each other's knowledge and skills, thereby stimulating reflection and broadening their perspective $[6,8]$. The brainstorming sessions provide the teachers with activities and ideas that create more effective teaching and ownership of teachers' own professional learning [8]. Furthermore, professional learning occurs when teachers have opportunities to work with experienced professionals in their subject areas, both inside and outside their schools, and have access to the wealth of experience of older and experience [10].

Feedback on teachers' professional development evaluation: There are dire needs for teachers to be evaluated after participating in various professional developments to assess the impacts of in-service professional development programmes on their teaching activities [11-15]. There must be series of follow up measures to determine if teachers are really experiencing professional growth. Most professional development activities do not assess or evaluate teachers after their participations in professional development programmes. This shows there is no concrete follow up on what teachers are learning in professional development activities, this does not encourage them to apply the knowledge in classroom teaching.

\section{Needs for in-service professional development}

The global world, most especially the developed countries such as United Kingdom, United States of America, Canada, Denmark, France and host of others have realized the importance of overhauling their teachers through adequate and specified professional development activities to develop their teachers for sustainability of quality education that can promote desired development in every facet of the society. Teachers determine the quality of education in any country; no country can be greater than the quality of teachers. Global changing and challenging roles of teachers have become more complex and more significant today. There is demand for them to be effective and result oriented teachers who can build vibrant learners, learners who can effect dynamic changes in economy, technology, political, social, cultural, and etc.

Teachers are to build citizenry who can interact smoothly in increasingly complex and interdependent geographical, economical and intellectual community with broader knowledge, tolerant attitudes and greater responsive skills. Teachers are saddled with huge responsibilities to produce responsive and high order thinking individuals in the society. Teaching is the mother of all professions; this is why teachers must have residual knowledge that can effect changes the society demands. Teachers teach various subjects that serve as building blocks for all professions. The quality of teachers determines the quality of education.

Nigeria, a country in Africa, known as developing country is struggling to catch up with the global trend of professional development. However, it is yet to be ascertained, the seriousness of government to realize the serious needs to regularly train and retrain Nigerian teachers in different levels of her education system, most especially primary and secondary schools teachers who lay foundations for professionals in different fields that universities train citizens in. There are cogent needs for teachers in Nigeria to be professional developed to serve their functions.

Teachers can only be effective and competent, if they are well knowledgeable and possess right skills to facilitate learning in classrooms. Knowledge is dynamic, that is why there is need for varieties of professional development activities that can improve their instructional tasks delivery. Competence and efficiency of teachers are measure with learners' academic performance. Curriculum documents are regularly reviewed to accommodate new knowledge that meets modern societal needs. Professional development activities are to be made available to all teachers, and have to be regularly done.

There is need to evaluate the teachers, to determine and to establish their areas of needs for professional development, when this is ascertained, competent programmes or facilitators should be employed to deliver. Evaluation of teachers to determine their needs for professional development activities help the teachers to acquire relevant skills that can be applied in their classroom teaching of the subjects.

Concerns for quality education in Nigerian education system are derived from needs and yearnings of teachers to improve academic performance of learners in schools. Teachers are saddled with great responsibilities of moulding learners who can propel developments in various facets of economy. Teachers are to produce learners who are responsive and skillful for nation's manpower. These vast expectations from teachers make them repositioned for in-service professional development activities that can increase their knowledge, skills, and attitudes necessary for optimum performance in their teaching profession.

Louise [15] enumerates the needs for professional development of teachers in Nigerian secondary schools as these:

Provision of sophisticated academic workforce as teaching personnel in the schools. 
- Empowerment of teachers with modern skills to boost human resource development in schools.

- Conforming to present information and communication technological advancements that befit the expectations of the modern teachers.

Amadi [14] agrees that human component forms the most important aspect of the resources in educational institutions. Incapacitated teachers in schools despites all the best infrastructures, sufficient funds and other non-human materials will result in poor academic performance of the learners. Teachers are the most important resources of the school; they need regular upgrading and overhauling to remain effective and productive in the education system.

Teachers need to understand and accept the importance of professional development in their profession beyond mere financial benefits and as means of empowering themselves. Teachers should not only see the financial gains of attending or participating in in-service professional activities but rather to improve their learners' academic performance. Kotsina supports the claim that professional development activities aim at promoting a lifelong quality education. Professional needs of teachers in Nigerian education system demand regular, relevant, purposeful and quality in-service professional activities that can sustain quality education.

\section{Learner-centred in-service professional development model}

Professional development activities are considered suitable and relevant, if teachers who undergo such trainings/activities can actually adopt learned experience to their teaching. Professional development activities in developed countries are developed and designed to have positive and measurable impacts on student learning. Learners are the focus of these activities. Selection of teachers for in-service professional development activities are basically done based on their classroom needs. Teachers are to select in-service professional development activities based on their needs for improvement on teaching and learning of their subjects. This is why they should be consulted in the conception and design of in-service professional development activities to cater for their urgent classroom challenges or improvement. All teachers must be given access to professional development, even the experienced and older teachers must partake regularly to affirm the knowledge, experience, skills they have acquired over the years in the profession to be abreast of modern trends in the subjects (Ravhuhali). New teachers are to be inducted into what is currently and practically in vogue in their subjects as against theoretical knowledge which they have acquired from educational institutions that award entry certificates into the profession. Professional development activities create awareness, equip and present realities in teaching and learning experience in schools and how they can effectively maximize the available resources and situations to facilitate learning in their learners.

Professional development activities are leveled grounds that consider varieties in teachers' teaching experiences, teaching levels, academic qualifications and learning environments; all utilized together to fashion learning experience, which can be applied to their peculiar classroom situations, in order to promote improved academic performance of the learners, after their participation in such professional development activities. In as much as teachers' choice of what type of in-service professional development to attend, there is also need for school administrators, who are well experienced in specific fields of learning to guide teachers on the needed professional development activities they can choose from or craft for themselves. Involvement of teachers in the conception and design of needed in-service professional development activities allow them to share teaching support resources, ideas, and experiences as well as brainstorming collectively on common and different challenges and proffer solutions (Hooker).

Experience as a teacher in Nigeria for over twenty years in primary and post primary schools has shown that teachers do not have autonomy over their curriculum development. Curriculum is drafted by those who are not classroom teachers, and they are in no better position to design functional and purposeful learning activities.

In view of the needed needs of the teachers for quality, relevant and applicable in-service professional development activities, this study develops sustainable and purposeful model for any professional development activity for teachers. Professional development of teachers in Nigeria must start with (1) Evaluation of teachers to identify the areas where they need professional development, (2) Identification of experienced facilitator-teachers, when planning professional development, the teachers need to be involve in the conception and designing professional development activities, they suggest facilitators that can influence or facilitate their desired changes or improvement, (3) Conveyance of Adult-learner teachers for these professional development activities should be available to every teacher identified to be in need of such, favourism in process of selection should be should be discarded, (4) When teachers come together from the same subject areas, they reason and brainstorm together on common issues and come up with common practical solutions which can be easily applied in their classroom teaching, (5) the ideal professional development promote acquisition of skills and knowledge that they deem fit for them and can be (6) applied to classroom teaching of their subjects, (7) this leads to improved academic performance of learners which can be measured in academic assessment, the results of learners academic performance provide (8) evaluation or feedback of subject-cluster experience teachers attend, the result or feedback, if not positive, propel the teachers to go through the process again. As illustrated in the Figure 1 below, this model if carefully implemented will always improve in academic performance of learners, sustainability of quality education and improved teaching and learning.

\section{Focus of In-Service Professional Development Activities}

Professional development activities of teachers are to develop/ improve teaching responsibilities, equip them with professional capacitation that ensure effective and efficient delivery of teaching and learning, which eventually lead to improved academic performance of students [12]. Teaching as a profession, in most prominent developed countries has been seen and taken as a valid means of igniting sustainability of development in different spheres of life. Teachers are heavily invested on in these countries; there is need to sustain and improve quality education. Professional development activities are designed for teachers to equip them with necessary skills and to make them relevant and competitive in the global community. These activities are thoroughly planned, executed, implemented and evaluated by teachers themselves and also the school management teams. Teachers are to be observed while teaching to identify the teaching gaps that need to be improved upon. They are to be evaluated to determine professional activities needed and also to be evaluated after the trainings to determine the improvement or impacts of the professional development they have attended.

Facilitation of learning in this present age requires the use of modern visual aids to concretize learning in various subjects. Teaching as gone beyond chalkboards and mere teacher-centred talk. There is paradigm 


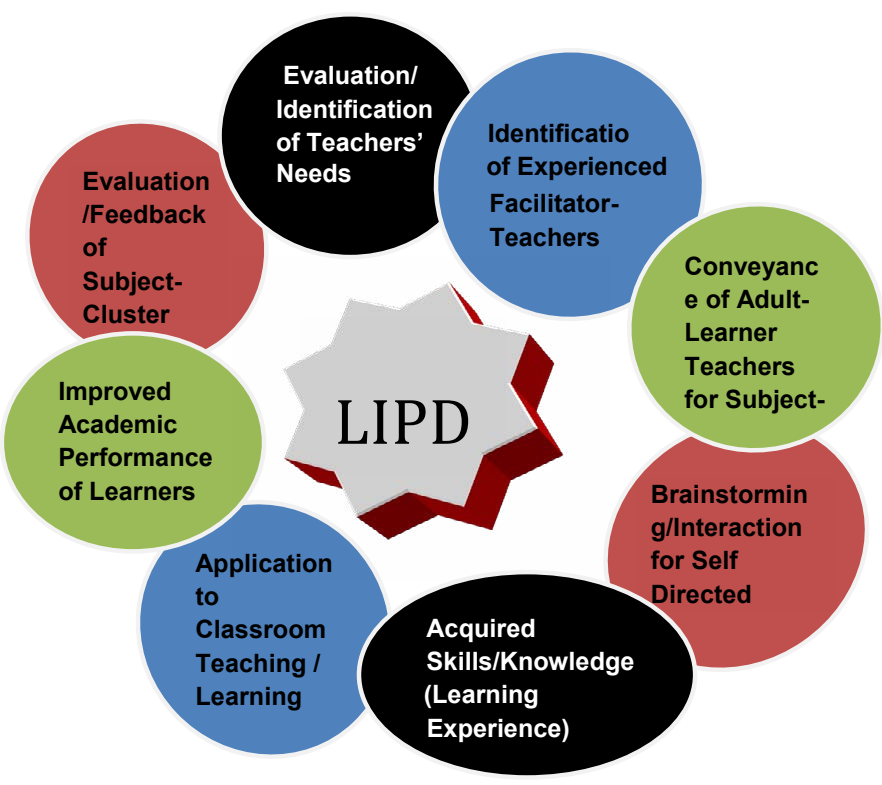

Figure 1: Learner-centred in-service professional development model (LIPD).

in instructional task delivery of teaching in classrooms; teachers are to engage learners in various activities with the use of electronic gadgets. So many gadgets have been designed to aid teaching/learning. Teachers can use projectors, tablets that are subject programmed, e-learning devices/materials and many more.

Teachers need to be familiar with the availability and use of these gadgets through professional development activities. These are learner centred approaches, they make teaching interesting and stress free, while actively engaging learners' participation in teaching and learning. Teachers from same subjects can cluster to share ideas on these innovations through professional development activities; they can also network with colleagues from any part of the society to share experience that can be applied in their classrooms.

It can be summarized that teachers, for them to be effective and fully actualize the goals of education in Nigeria, they deserve universal access to regular, well packaged and designed, effective and quality inservice professional development activities in every level of education. These professional development activities are accessed through workshops, seminars, refreshers' courses/retreats, conferences and other professionally inclined activities for the teachers. The activities expose teachers to:

- Use and application of modern visual aids in teaching subject areas and empowerment of learners in the usage of same.

- Efficient and varied learner-centred approaches to teaching of their subjects in classrooms.

- Deep, highly intellectual and increased knowledge or skills in their specialized subjects in schools.

- Collaboration and professional networking among teachers in different locations of the world.

- Development of problem solving skills that grooms them as researchers in their teaching fields.

- Comparative of better academic performance of their learners.

\section{Challenges of In-Service Professional Development}

Effectiveness of teachers remains the priority of any in-service professional activity. However, so many issues militate against the purpose of professional development of teachers in Nigeria.

Yinusa concludes that teacher professional development activities have failed the purpose in real practice of teaching due to various identified problems. These challenges were identified:

Inability of the in-service professional development activities to meet the needs and expectations of the participating teachers. My experienced as a teacher in Nigeria for many years and interactions with colleagues reveal that teachers who have participated in various in-service professional development activities lamented that most of these activities did not benefit their teaching skills in classrooms. Teachers rated these trainings as mere wasting of their precious time as their key expectations and needs were never met or attended to. Subject teachers are made to attend professional development workshops that do not relate to their subject areas, when this happen, they return to their classrooms with no impacts of the workshops they have attended.

Inappropriate professional activities to suit instructional tasks delivery in classroom was also identified as shortfall of professional development by teachers. Various subjects demand varied teaching skills and approaches that promote effective teaching and learning of various subject-contents: these varieties, teachers decried were not considered as teachers of different specialization were hurled together for same professional development activities that did not consider or embed their individual subjects. Professional development activities should have targeted participants who can richly benefit from the experience. Professional development programmes should be well tailored to address the needs of teachers in their subject areas.

Another prominent challenge of professional development of teachers was the limited number of teachers that could access in-service professional development trainings in Nigeria. Many teachers were not opportuned to participate, and those who participated were not 
frequently trained. Most time when teachers are called for professional development trainings, several conditions are used to select or admit teachers into such programmes. These selection guidelines do not allow teachers to be developed universally, sometimes, favourism and nepotism influence the choice of teachers to be selected. This denies most teachers from accessing professional development activities.

Okwunaso and Igwebuike submit the inability of the participating teachers in professional development activities to apply or adapt the knowledge experienced or acquired in the training to classroom as a big challenge to usefulness of in-service professional development [13]. Innovation of new approaches or ideas in teaching do not manifest in classroom teaching after teachers' participation in these elaborated trainings. Sometimes, lack of readiness to accept change in teaching methods, makes some teachers who attend such professional development activities. When teachers are not motivated to their satisfactions, they tend to resist application of new experience in their classroom teachings. If the professional development activities are multi-tasks, so teachers who resist challenges in their skills may refuse.

\section{Recommendations and Conclusion}

Education is the wheel of development. Teachers are the major stakeholders that determine or affect the quality of education; it is only the quality education that can promote necessary developments across the country. Nigerian education system is the propeller for development in all ramifications just like other developed countries; teachers are the drivers to that developmental knowledge that can be used to attain total development. Teachers who will facilitate learning should be efficient in instructional tasks delivery of knowledge, skills, values and attitudes. Professional development activities are designed or aimed at effectiveness and efficiency of teachers in schools. Due to these, varied in-service professional development programmes/ activities are to be structured and designed to implement National policy of Education in Nigeria [14,15]. Professional development could also be well designed to introduce teachers to new curricula, new ideas, and new approaches to teaching. Their knowledge and skills can also be updated on their subject matters through collaborations of ideas, mentorship opportunities among teachers and skills acquisition and changed attitudes to arsenal all facilities in educational system.

To ensure effectiveness of in-service professional development activities among Nigerian teachers, there is need for organizers of various in-service professional developments of teachers to design contents of professional development activities according to subject areas of the participating teachers for the programmes. This boils down to consultations with teachers to know their teaching challenges and their urgent expectations. Regular information needs to be sought from teachers to know their actual areas of needs that can be fixed to promote better teaching abilities in schools. Assessment of teachers should be done based on subjects, grades of learners, locations of the schools, teachers' perceptions and readiness for new knowledge.

This study recommends that every teacher should be allowed to access various in-service professional development activities regularly every year to update them. Numbers of participating teachers should be increased at every professional development programme to accommodate many teachers at every session of the professional development. Teachers universally in different parts of Nigeria, different classes of learners should be allowed to participate in professional development activities at regular intervals for sustainability of professional development.
Pre-assessment and post-assessment of professional development programmes should be carried out for every activity of professional development. This will ensure application of knowledge and efficacy of the programme in classroom situations. Assessment before teachers are sent for professional development activities to determine their needs for professional development, while it is also necessary to assess them after attending professional development activities to measure impacts of new knowledge on teaching activities.

Attendance and participation of teachers in in-service professional development programmes should be motivated based on improvement in quality of academic performance of learners in subjects. In as much as professional development activities aim at improving learners' performance in their academic studies, teachers also believe that there should be financial bonus or rewards and salary progression that will always prompt them to develop their teaching skills. OECD's (2010) reveals that IPD of teachers in developed countries like Portugal, Poland, Slovakia, and Slovenia determine their salary increase and career advancement. Australian teachers enjoy regular and universals access to IPD though schools supplementary funds for professional development activities in various capacities that can aid their teaching skills to promote improved academic performance of their learners. Nigerian teachers demand financial gains from participating in various professional development activities. Attendance could also be used to determine career progression for them to ensure committed participation.

OECD shows that teachers in Luxembourg and Spain, who participate in measurable numbers of professional development programmes are entitled to a salary bonus, whereas in other countries, participations in IPD are counted as credits for promotional exercises. UNESCO discloses that teachers in developing African countries like Nigeria are poorly remunerated. Poor enumeration of teachers affect their performance, highly motivated teachers are the ones that can actually give their best to instructional delivery.

\section{References}

1. Mkhwanazi S (2014) Crossing the past political boundary: Teacher professional learning in South African Reform Context Mediterranean Journal of Social Sciences 5: 425-432.

2. Bantwini BD (2009) District professional development models as a way to introduce Primary School Teachers to Natural Science Curriculum Reforms in one district in South Africa. Journal of Education for Teaching 35: 162-189.

3. Steyn GM (2008) Continuing professional development for teachers in South Africa and social learning systems: Conflicting conceptual frameworks of learning Koers 73: 15-31.

4. Garet MS, Porter AC, Desimone L, Birman BF, Yoon KS, et al. (2001) What makes professional development effective? Results from a national sample of teachers. American Educational Research Journal 38: 915-945.

5. Hirsh S (2005) Professional development and closing the achievement gap. Theory into Practice 44: 38-44.

6. Lee HL (2005) Developing a professional development programme mode based on teachers' needs. The Professional Educator 27: 39-49.

7. Desimone LM, Smith TM, Ueno K (2006) Are teachers who sustained contentfocused professional development getting it? An administrator's dilemma. Educational Administration Quarterly 42: 179-215.

8. Dymoke S, Harrison JK (2007) Professional development and the beginning teacher: issues of teacher autonomy and institutional conformity in the performance review process. Journal of Education for Teaching 32: 71-92.

9. Van Eekelen, IM Vermunt JD, Boshuizen HPA (2006) Exploring teachers' will to learn Teaching and Teacher Education 22: 408-423.

10. Robinson R, Carrington S (2002) Professional development for inclusive schooling. International Journal of Educational Management 16: 239-247. 
Citation: Ajani OA (2018) Needs for In-service Professional Development of Teachers to Improve Students' Academic Performance in Sub-Saharan Africa. Arts Social Sci J 9: 330. doi: 10.4172/2151-6200.1000330

Page 7 of 7

11. Lam YLJ, Pang SN (2003) The relative effects of environmental internal and contextual factors on organisational learning: the case of Hong Kong schools under reforms. The Learning Organisation 10: 83-97.

12. Adesina S (2005) Growth with development: Nigeria's educational experience between 1914-2004 Abeokuta: Educational Industries Ltd.
13. Okwuanaso SI, Igwebuike SA (2006) Education and development: Perspective on teachers; attitude to work African. Journal of Research in Education 1: 21-25.

14. Amadi EC (2008) Administration and personnel development in adult and community education A Module: Port Harcourt: Harey Publications Port Harcourt.

15. Louise S (2008) Teacher effectiveness. 